Pesq. Vet. Bras. 37(9):949-957, setembro 2017 DOI: $10.1590 / \mathrm{S} 0100-736 \mathrm{X} 2017000900009$

\title{
Caracterização anatomopatológica e bacteriológica em frangos de corte condenados totalmente por colibacilose sob Serviço de Inspeção Federal ${ }^{1}$
}

\author{
Renata A. Casagrande ${ }^{2,3}$, Gustavo Machado ${ }^{3}$, Priscila R. Guerra ${ }^{3}$, Luiza A. Castro ${ }^{4}$, \\ Andréia Spanamberg ${ }^{3}$, Sérgio C. Silva ${ }^{4}$, Marisa R. de Itapema Cardoso ${ }^{5}$ \\ e David Driemeier ${ }^{4 *}$
}

\begin{abstract}
Casagrande R.A., Machado G., Guerra P.R., Castro L.A., Spanamberg A., Silva S.C., Cardoso M.R.I. \& Driemeier D. 2017. [Pathological and bacteriological characterization on broilers totally condemned due to colibacillosis under the control of the Federal Inspection Service.] Caracterização anatomopatológica e bacteriológica em frangos de corte condenados totalmente por colibacilose sob Serviço de Inspeção Federal. Pesquisa Veterinária Brasileira 37(9):949-957. Setor de Patologia Veterinária, Faculdade de Veterinária, Universidade Federal do Rio Grande do Sul, Av. Bento Gonçalves 9090, Bairro Agronomia, Porto Alegre, RS 91540-000, Brazil. E-mail: davetpat@ufrgs.br

Colibacillosis is the main infectious cause of total carcass condemnation in broilers in southern Brazil. This study aims to determine the degree of agreement between the total carcass condemnation for colibacillosis in broilers slaughtered in establishments under Federal Inspection Service (SIF) with the pathological and bacteriological diagnosis. The study was conducted with 45 broilers totally condemned by colibacillosis (case) and theirs 45 respective controls (chickens without lesions). All broilers condemned had gross lesions and the controls had not. The Kappa-Cohen's test showed that these two variables had almost perfect agreement. Broilers condemned showed lesions in liver (27/45); liver and air sacs (11/45); liver and heart (2/45); liver, heart and air sacs (2/45); liver, air sacs and oviduct (1/45); liver, air sacs, heart and subcutaneous (1/45); and liver, air sacs, oviduct and spleen (1/45). There is almost perfect agreement between carcass condemnation and liver damage. Histologically, in 41 cases and 12 controls were observed lesions, the most frequent diagnoses were random necrotizing hepatitis, fibrinous-heterophilic bronchitis, acute pericarditis and lymphoplasmacytic tracheitis. In hepatitis cases was isolated Escherichia coli, Enterococcus sp. and Streptococcus sp. (10/38) and in bronchitis or bronchopneumonia E. coli and coagulase positive Staphylococcus (9/14). The polymerse chain reaction (PCR) and immunohistochemistry (IHC) tests for Mycoplasma gallisepticum and M. synoviae were negative. In cases of total carcass condemnation by Colibacillosis the liver was the main organ affected. Therefore, the condemnation criteria should be revised, suggesting conviction for hepatitis in these cases, because other bacteria can cause hepatitis, as demonstrated in this study.
\end{abstract}

INDEX TERMS: Broiler, colibacilosis, condemnation, Federal Inspection, bacterial disease, pathology, poutry, abattoir.

\footnotetext{
${ }^{1}$ Recebido em 3 de abril de 2016.

Aceito para publicação em 19 de março de 2017.

${ }^{2}$ Laboratório de Patologia Animal, Centro de Ciências Agroveterinárias, Universidade do Estado de Santa Catarina, Av. Luís de Camões 2090, Bairro Conta Dinheiro, Lages, SC 88520-000, Brasil.

${ }^{3}$ Programa de Pós-Graduação em Ciências Veterinárias, Faculdade de Veterinária (FaVet), Universidade Federal do Rio Grande do Sul (UFRGS),
}

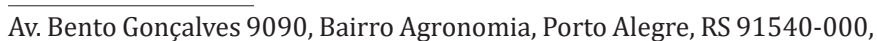
Brasil.

${ }^{4}$ Setor de Patologia Veterinária, FaVet/UFRGS, Av. Bento Gonçalves 9090, Bairro Agronomia, Porto Alegre, RS 91540-000, Brasil. *Autor para correspondência: davetpat@ufrgs.br

${ }^{5}$ Setor de Medicina Veterinária Preventiva, FAVET/UFRGS. Av. Bento Gonçalves 9090, Bairro Agronomia, Porto Alegre, RS 91540-000, Brasil. 
RESUMO.- A colibacilose é a principal causa infecciosa de condenação total de carcaça em frangos de corte no sul do Brasil. Esse trabalho tem por objetivo determinar o grau de concordância entre a condenação total por colibacilose de frangos de corte abatidos em estabelecimento sob Serviço de Inspeção Federal (SIF) com o diagnóstico anatomopatológico e bacteriológico. 0 estudo foi realizado com 45 frangos de corte condenados totalmente por colibacilose (caso) e seus respectivos 45 controles (frangos sem lesões). Em todos os frangos condenados pelo SIF havia lesões macroscópicas e, nos controles não se observou. Através do teste Kappa-Cohen's essas duas variáveis apresentaram concordância quase perfeita. As aves condenadas apresentaram lesões em fígado (27/45); em fígado e sacos aéreos (11/45); em fígado e coração (2/45); fígado, sacos aéreos e coração (2/45); fígado, sacos aéreos e oviduto (1/45); fígado, sacos aéreos, coração e tecido subcutâneo (1/45); e fígado, sacos aéreos, oviduto e baço (1/45). Observou-se concordância quase perfeita entre condenação e lesão hepática. Histologicamente, em 41 casos e 12 controles observaram-se lesões, sendo os mais frequentes hepatite necrosante aleatória, bronquite fibrino-heterofílica, pericardite aguda e traqueíte linfoplasmocitária. Nas aves com hepatite identificou-se E. coli, Enterococcus sp. e Streptococcus sp. $(10 / 38)$ e, nas aves com bronquite ou broncopneumonia isolou-se Escherichia coli e Staphylococcus coagulase positiva (9/14). O PCR em tempo real e a imuno-histoquímica para Mycoplasma gallisepticum e M. synoviae foram negativos. Nos casos de condenação total por colibacilose o fígado foi o principal órgão acometido, portanto, o critério de condenação deveria ser revisto, sugerindo condenação por hepatite nesses casos, já que outras bactérias podem causar hepatite, como foi demonstrado nesse estudo.

TERMOS DE INDEXAÇÃO: Frangos de corte, colibacilose, condenação, Inspeção Federal, doença bacteriana, patologia, ave, abatedouro.

\section{INTRODUÇÃO}

As doenças respiratórias são as principais responsáveis por condenações de carcaça na indústria avícola brasileira. As altas concentrações de amônia no galpão, a deficiência na ventilação de ambientes avícolas, os extremos de temperatura, a umidade da cama, as criações com alta densidade e a deficiência no processo de desinfecção são fatores ambientais predisponentes para o desencadeamento desses problemas respiratórios (Ferreira \& Knöbe 2008).

A colibacilose é a principal causa infecciosa de condenação total de carcaça em frigoríficos de frangos de corte no sul do Brasil (Giotto et al. 2008, Sesterhenn et al. 2011). A colibacilose aviária caracteriza-se por uma infecção localizada ou sistêmica causada por Escherichia coli patogênica para aves (APEC). Essa enfermidade tem inúmeras formas de apresentação, no entanto a infecção mais usual é a do trato respiratório que evolui para colisepticemia (Janben et al. 2001, Barnes et al. 2008, Kabir 2010).

Em frangos de corte, na maior parte dos casos, os problemas respiratórios não envolvem apenas um agente. A bactéria E. coli participa com maior frequência, no entanto, outras enfermidades como a micoplasmose, a bronquite infecciosa, a doença de Newcastle, a laringotraqueíte infecciosa, a coriza infecciosa, a influenza aviária, a cólera e a aspergilose também podem estar envolvidas (Ferreira \& Knöbe 2008).

Mycoplasma gallisepticum (MG) e M. synoviae (MS) são considerados responsáveis por causar doença respiratória branda em frangos de corte, porém quando ocorre infecção simultânea com outros agentes patogênicos e/ou condições de manejo inadequadas, o quadro clínico-patológico pode ser severo (Gross 1961, Fabricant \& Levine 1962, Gross 1990, Ley 2008, Kleven \& Ferguson-Noel 2008). As lesões no trato respiratório aumentam as condenações de carcaças em abatedouros (Minharro et al. 2001, Sentíes-Cué et al. 2005, Machado et al. 2012) e tornam as aves mais susceptíveis a infecções secundárias, principalmente por E. coli (Alencar et al. 1998, Kleven \& Ferguson-Noel 2008, Ley 2008).

A avaliação e o estudo de lesões encontradas durante o abate de aves em frigoríficos são reconhecidos como um método importante de monitoramento de enfermidades em criações comerciais (Ansong-Danquah 1987). No Brasil não há estudos que correlacionem às lesões macroscópicas de causa infecciosa observadas em abatedouros de frango de corte com a caracterização histológica e o isolamento do agente presente nos órgãos lesionados. Essa tríade de diagnóstico é fundamental para que se estimem o real impacto dos agentes infecciosos como causa de condenação de carcaças.

Esse trabalho tem por objetivo: (1) determinar o grau de concordância entre a condenação total por colibacilose de frangos de corte abatidos em estabelecimento sob Serviço de Inspeção Federal (SIF) do estado do Rio Grande do Sul com o diagnóstico anatomopatológico; (2) caracterizar as lesões anatomopatológicas encontradas em frangos de corte com condenação total por colibacilose; (3) realizar reação em cadeia da polimerase (PCR) e imuno-histoquímica (IHQ) para MG e MS; (4) realizar isolamento bacteriano dos órgãos com lesões.

\section{MATERIAL E MÉTODOS}

Definição da população-alvo e plano amostral. Utilizaram-se frangos de corte em idade de abate (35-45 dias) provenientes de um abatedouro sob SIF, localizado no estado do Rio Grande do Sul. 0 estudo foi conduzido nos frangos com condenação total por colibacilose.

O número mínimo de amostras a serem coletadas seguiu os seguintes parâmetros: a população de estudo $(\mathrm{N})$ foi o número médio de aves abatidas/dia (470.000 aves/dia) no referido abatedouro e foi considerada uma prevalência a priori de $0,125 \% \mathrm{em}$ condenação total por colibacilose (dado obtido junto ao SIF), nível de confiança de $90 \%$ e erro $\alpha$ de $10 \%$, resultando numa amostra mínima de 42 aves/dia. Para cada ave condenada por colibacilose (caso), uma ave normal do mesmo lote também foi coletada de forma aleatória (controle).

Critério de condenação. A avaliação e a condenação das carcaças foram realizadas pelos funcionários do SIF de acordo com os critérios de condenação de carcaça de aves estabelecidos pelo Ministério da Agricultura, Pecuária e Abastecimento (MAPA). Em relação a colibacilose, qualquer órgão ou parte da carcaça que 
estivesse afetado por um processo inflamatório era condenado (condenação parcial) e, quando havia evidência sistêmica do problema, a carcaça a as vísceras eram, na sua totalidade, condenadas (condenação total) (Brasil 1998).

Colheita e processamento de amostras. Realizaram-se cinco coletas, com intervalo de dois dias cada, todas no mês de outubro de 2012. Em cada dia de coleta, 10 frangos (uma ave por lote) condenados totalmente por colibacilose (caso) foram coletados, diretamente na linha de inspeção, totalizando 50 aves. De cada lote, colheu-se um frango normal (controle). Devido a falta de órgãos para a análise, que foram perdidos durante a coleta no abatedouro, exclui-se cinco casos e seus respectivos controles, restando assim 45 casos com os respectivos controles.

Durante o transporte, as aves abatidas foram mantidas refrigeradas por no máximo seis horas. Todas as aves foram pesadas e após realizou-se a necropsia no Setor de Patologia Veterinária (SPV) da FaVet/UFRGS. Fragmentos de traqueia, pulmão, sacos aéreos, coração, fígado, baço, rins, nervo ciático, pele, medula óssea, bursa de Fabrícius, timo, esôfago, proventrículo, moela, intestino delgado e grosso foram colhidos, fixados em formalina tamponada a $10 \%$, processados rotineiramente para análise histopatológica e coradas pela técnica de hematoxilina e eosina (HE). Colorações especiais, como Tricrômico de Masson (TM) e hematoxilina ácida fosfotúngstica de Mallory (PTAH) foram realizadas em pulmão, fígado e sacos aéreos com lesões histológicas.

Suabes de traqueia, bem como fragmentos de pulmão e fígado de todas as aves foram congelados a $-20^{\circ} \mathrm{C}$ para realização de exame microbiológico e PCR.

Exame microbiológico. As amostras congeladas de fígado e pulmões com lesões compatíveis com infecção bacteriana detectadas pelo exame histopatológico foram encaminhadas para cultivo bacteriano. Os fragmentos foram colhidos assepticamente e submetidos ao cultivo bacteriano aeróbio em meio ágar sangue e ágar MacConkey. As amostras foram incubadas a $37^{\circ} \mathrm{C}$, durante 24-72 horas. Após, realizou-se a identificação bacteriana pela observação macroscópica das colônias, da morfologia microscópica e do perfil bioquímico dos isolados. Os testes bioquímicos empregados foram a detecção das enzimas catalase, verificação de citocromo oxidase, fermentação de carboidratos, produção de urease, hidrólise de gelatina, utilização de citrato e degradação de aminoácidos.

Realizou-se também a pesquisa de Salmonella sp. nas amostras. Utilizou-se para o enriquecimento seletivo o caldo Tetrationato e caldo Rappaport-Vassiliadis, ambos foram incubados a $42^{\circ} \mathrm{C}$ por 24 horas. Após, as amostras foram plaqueadas em meio ágar XLD e incubadas a $37^{\circ} \mathrm{C}$ durante 48 horas. A identificação dos isolados foi realizada utilizando a caracterização do perfil bioquímico, a verificação de citocromo oxidase, produção de urease, fermentação da glicose, sacarose e lactose em meio TSI (triple sugar iron agar), detecção da beta-galactosidade, descarboxilação da lisina, produção de $\mathrm{H}_{2} \mathrm{~S}$ (sulfureto de hidrogênio), motilidade e produção de indol. Para a confirmação final foi realizada a prova de soroaglutinação.

Imuno-histoquímica para Mycoplasma gallisepticum e M. synoviae. Dos casos de condenação por colibacilose em que evidenciou-se lesão inflamatória em pulmões, traqueia e sacos aéreos, esses foram submetidos à IHQ anti-MG e anti-MS conforme descrito por Yilmaz et al. (2011a, Yilmaz. \& Timurkaan 2011b) e adaptado por Casagrande et al. (2014).

PCR em tempo real para a detecção de $M$. gallisepticum e $\boldsymbol{M}$. synoviae. Realizou-se PCR em tempo real para MG e MS de suabe de traqueia dos frangos condenados por colibacilose e seus respectivos controles. O DNA total foi extraído e purificado a partir dos suabes de traqueia utilizando o kit comercial QIAamp DNA Mini Kit (Qiagen ${ }^{\circledR}$ ) de acordo com as instruções do fabricante. Para avaliar a qualidade do DNA extraído e a presença de possíveis inibidores na reação, foram adicionados $2 \mu \mathrm{L}$ /amostra de controle interno positivo (VetMAX Xeno Internal Positive Control, Life Technologies ${ }^{\circledR}$ ) no tampão de lise antes da extração. Os DNAs foram recuperados em um volume de eluição de 100 e utilizados $5 \mu \mathrm{L}$ de DNA em cada reação. Todas as reações de PCR em tempo real foram realizadas conforme Casagrande et al. (2014).

Imuno-histoquímica para marcadores celulares. Dos casos de condenação por colibacilose em que observou-se lesão em pulmões e fígado, esses foram submetidos à IHQ para caracterização do infiltrado inflamatório. Utilizou-se os anticorpos primários anti-citoqueratina (clones AE1/AE3, DakoCytomation ${ }^{\circledR}$, diluição 1:80) e anti-lisozima (Clone EC 3.2.1.17, DakoCytomation, diluição 1:200). 0 bloqueio da atividade da peroxidase endógena foi realizado com peróxido de hidrogênio a $10 \%$ em metanol. Para a recuperação antigênica utilizou-se tampão citrato, $\mathrm{pH} 6$ a $125^{\circ} \mathrm{C}$ para citoqueratina e proteinase K (DakoCytomation ${ }^{\circledR}$ ) para lisozima. 0 bloqueio das reações inespecíficas foi feito com leite desnatado Molico ${ }^{\circledR}$ a $5 \%$. Utilizou-se anticorpo secundário biotinilado ligado a estreptavidina-peroxidase (kit LSAB-HRP, K0690, DakoCytomation ${ }^{\circledR}$ ) e o cromógeno 3,3'diaminobenzidina (DAB, K3468, DakoCytomation ${ }^{\circledR}$ ). Como controle positivo foi utilizado um corte histológico de carcinoma (citoqueratina) e um histiocitoma canino (lisozima).

Análises estatísticas. Para análise dos dados, os mesmos foram armazenados em planilhas Excel e analisados por meio de estatística descritiva, distribuição de frequências, construção de tabelas de contingência e teste de concordância Kappa-Cohen's. Todas as análises foram realizadas no R v.2.15.2 ( $R$ develepment Core Team, 2011). 0 estudo contou com proporção de casos e controles da ordem de $m: m$ (1:1). Foi utilizado para efeito de todas análise valor de $\mathrm{P}$ significativo quando $\leq 0.05$.

\section{RESULTADOS}

Nesse estudo foram coletados 45 frangos de corte condenados totalmente por colibacilose (caso) e seus respectivos 45 controles. Cada caso pareado ao controle era proveniente de um lote, totalizando 45 lotes, originários de 22 produtores, distribuídos em 12 municípios diferentes, do estado do Rio Grande do Sul. O número total de aves abatidas por lote foi de 14.232 a $64.924(\mu=40.290)$. O percentual de condenação total por colibacilose nesses lotes variou de 0,0027 a $0,0877 \%(\mu=0,025 \%)$. Quanto ao peso dos frangos condenados e controles, esse variou de $0,6 \mathrm{~kg}$ a $1,52 \mathrm{~kg}$ $(\mu=1,081 \mathrm{~kg} ; \mathrm{CI}=0,184 \mathrm{~kg})$.

Dos 45 frangos condenados pelo SIF, todos apresentaram alterações macroscópicas e, das 45 aves controles não se observou lesão (Quadro 1). Dos 45 frangos com lesões macroscópicas, 41 apresentaram lesões histológicas e dos 45 controles que não tinham lesões macroscópicas, 12 apresentaram lesões histológicas conforme pode ser observado no Quadro 2.

Utilizando o teste Kappa-Cohen's para avaliar o grau de concordância entre essas variáveis, observou-se que condenação e avaliação macroscópica apresentam concordância quase perfeita (Kappa $=1 / \mathrm{p}<0,05)$, condenação e histopatologia (Kappa $=0,644 / \mathrm{p}<0,05)$, bem como avaliação macroscópica e histopatologia com concordância substancial (Kappa $=0,644 / \mathrm{p}<0,05)$.

Quanto à distribuição das lesões macroscópicas, as aves condenadas por colibacilose apresentaram alterações em 
Quadro 1. Frequência de frangos de corte condenados totalmente por colibacilose e dos controles quanto a presença de lesões macroscópicas

\begin{tabular}{lccc}
\hline & Ausência de lesões & Presença de lesões & Total \\
\hline Controle & 45 & 0 & 45 \\
Condenado & 0 & 45 & 45 \\
Total & 45 & 45 & 90
\end{tabular}

Quadro 2. Frequência de frangos de corte condenados totalmente por colibacilose e dos controles com lesões macroscópicas e histológicas

\begin{tabular}{lccc}
\hline \multirow{2}{*}{ Lesão histológica } & \multicolumn{3}{c}{ Lesão macroscópica } \\
\cline { 2 - 4 } & Ausente & Presente & Total \\
\hline Ausente & 33 & 4 & 37 \\
Presente & 12 & 41 & 53 \\
Total & 45 & 45 & 90
\end{tabular}

fígado (27/45); em fígado e sacos aéreos (11/45); em fígado e coração (2/45); fígado, sacos aéreos e coração (2/45); fígado, sacos aéreos e oviduto (1/45); fígado, sacos aéreos, coração e tecido subcutâneo (1/45); e fígado, sacos aéreos, oviduto e baço (1/45).

Para avaliar o grau de concordância entre a condenação por colibacilose e a presença de lesão macroscópicas nos diferentes órgãos utilizou-se o teste Kappa-Cohen's. Havia concordância quase perfeita entre condenação e lesão no fígado (Kappa=0,844/p<0,05), concordância leve com lesão no coração (Kappa=0,244/p<0,05), concordância pobre com lesão em sacos aéreos (Kappa=0,133/p<0,05) e, nenhuma concordância com lesão em traqueia (Kappa $=-0,666 / \mathrm{p}<0,05)$.

Das 45 aves com lesões macroscópicas no fígado, em 38 também evidenciou-se lesões histológicas. A macroscopia desses casos era caracterizada principalmente por fígado moderadamente aumentado de tamanho com pontos esbranquiçados de 1 a $5 \mathrm{~mm}$, firmes, multifocais a coalescentes com aspecto estrelado e esverdeado, na superfície capsular (Fig.1A) e parênquima (30/38) e com deposição de fibrina sobre a cápsula (7/38); e severamente aumentado, firme, padrão lobular e ductos biliares evidentes (Fig.1B) (1/45). Nos sete casos em que se observou lesões macroscópicas, porém sem alterações histológicas, essas eram caracterizadas por aumento discreto associado a manchas esverdeadas (3/7); coloração pálida e padrão lobular discretamente evidente (2/7); coloração vermelho-escura e pontos esbranquiçados de $1 \mathrm{~mm}$ multifocais na superfície capsular
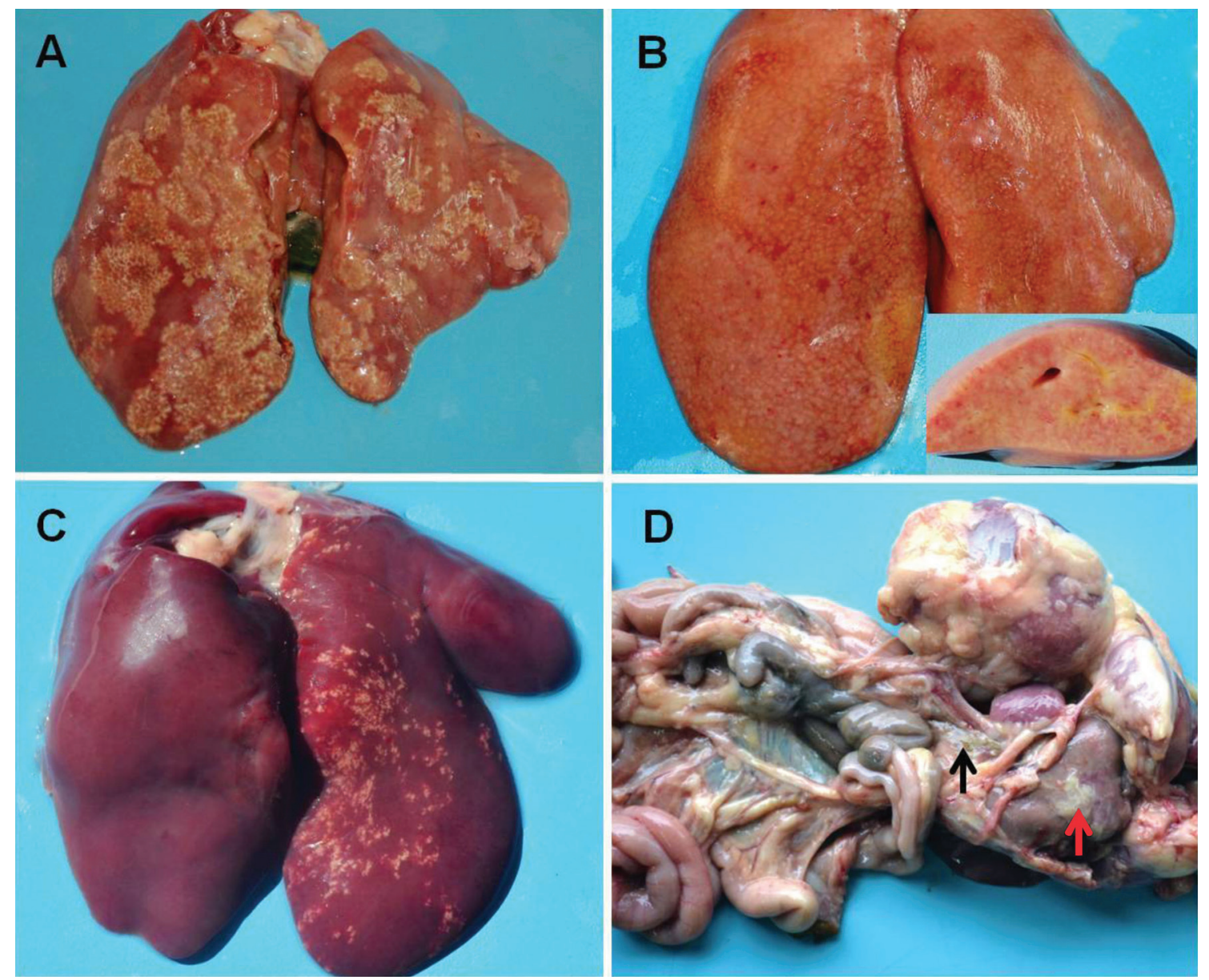

Fig.1. Frangos de corte condenados totalmente por colibacilose. (A) Fígado moderadamente aumentado de tamanho com pontos esbranquiçados de 1 a $5 \mathrm{~mm}$, firmes, multifocais a coalescentes com aspecto estrelado, na superfície capsular. (B) Fígado severamente aumentado e padrão lobular evidente. Destaque: superfície de corte com padrão lobular e ductos biliares evidentes. (C) Fígado com coloração vermelho-escura e lobo esquerdo com pontos esbranquiçados de $1 \mathrm{~mm}$ multifocais na superfície capsular. (D) Sacos aéreos (seta preta) e fígado com moderada deposição de fibrina (seta vermelha). 
Quadro 3. Caracterização das lesões histopatológicas em frangos de corte condenados totalmente por colibacilose

\begin{tabular}{llc}
\hline Órgão & \multicolumn{1}{c}{ Diagnóstico histopatológico } & No animais \\
\hline Fígado & Hepatite necrosante aleatória & 33 \\
& Hepatite aguda aleatória & 2 \\
& Hepatite crônica-ativa & 3 \\
Pulmões & Bronquite fibrino-heterofílica & 11 \\
& Broncopneumonia fibrino-heterofílica & 2 \\
& Broncopneumonia fibrino-heterofílica & 1 \\
& necrótica & \\
& Hiperplasia do tecido linfoide & 6 \\
& peribronquial (BALT) & 1 \\
Coração & Trombose pulmonar & 14 \\
& Pericardite aguda & 1 \\
Traqueia & Pericardite crônica & 13 \\
Sacos aéreos & Traqueíte linfoplasmocitária & 4 \\
& Aerossaculite aguda & 2 \\
Oviduto & Aerossaculite crônica & 2 \\
Baço & Salpingite aguda & 1 \\
Subcutâneo & Esplenite aguda & 1
\end{tabular}

(Fig.1C) (1/7); e palidez com manchas avermelhadas (1/7).

Macroscopicamente, as lesões observadas em sacos aéreos eram caracterizadas por moderada deposição de espuma (14/16) e espessamento com moderada deposição de material fibrinocaseoso (Fig.1D) (2/16). No coração evi- denciou-se, em saco pericárdico, deposição de fibrina difusa moderada (1/4) ou discreta (2/4) e líquido translúcido moderado (1/4). 0 oviduto estava com lúmen preenchido por material fibrinocaseoso $(2 / 2)$, o baço diminuído de tamanho e recoberto por fibrina (1/1) e o tecido subcutâneo com deposição de material fibrinocaseoso moderado (1/1).

$\mathrm{Na}$ avaliação histopatológica dos casos condenados por colibacilose, 38 apresentaram lesão em fígado, 13 em pulmões e coração, seis em sacos aéreos e traqueia. Das 45 aves controles que não apresentavam lesões macroscópicas, em 12 havia lesões histopatológicas, sendo nove em traqueia, sete em pulmões e duas em coração. A caracterização das lesões histológicas encontra-se no Quadro 3.

A principal lesão histológica nos casos de colibacilose foi em fígado. 0 diagnóstico mais prevalente foi de hepatite necrosante aleatória que era caracterizada por necrose fibrinoide multifocal a coalescente variando de discreta a acentuada, circundada por intenso infiltrado de heterófilos, macrófagos, linfócitos e plasmócitos (Fig.2A). Em muitos casos havia focos de necrose circundada por macrófagos e células gigantes multinucleadas. Pela coloração de PTAH pode-se comprovar filetes delgados de fibrina nas áreas de necrose (Fig.2B). Nesses casos havia também infiltrado de heterófilos, macrófagos, linfócitos e plasmócitos multifocal moderado a acentuado na região portal.
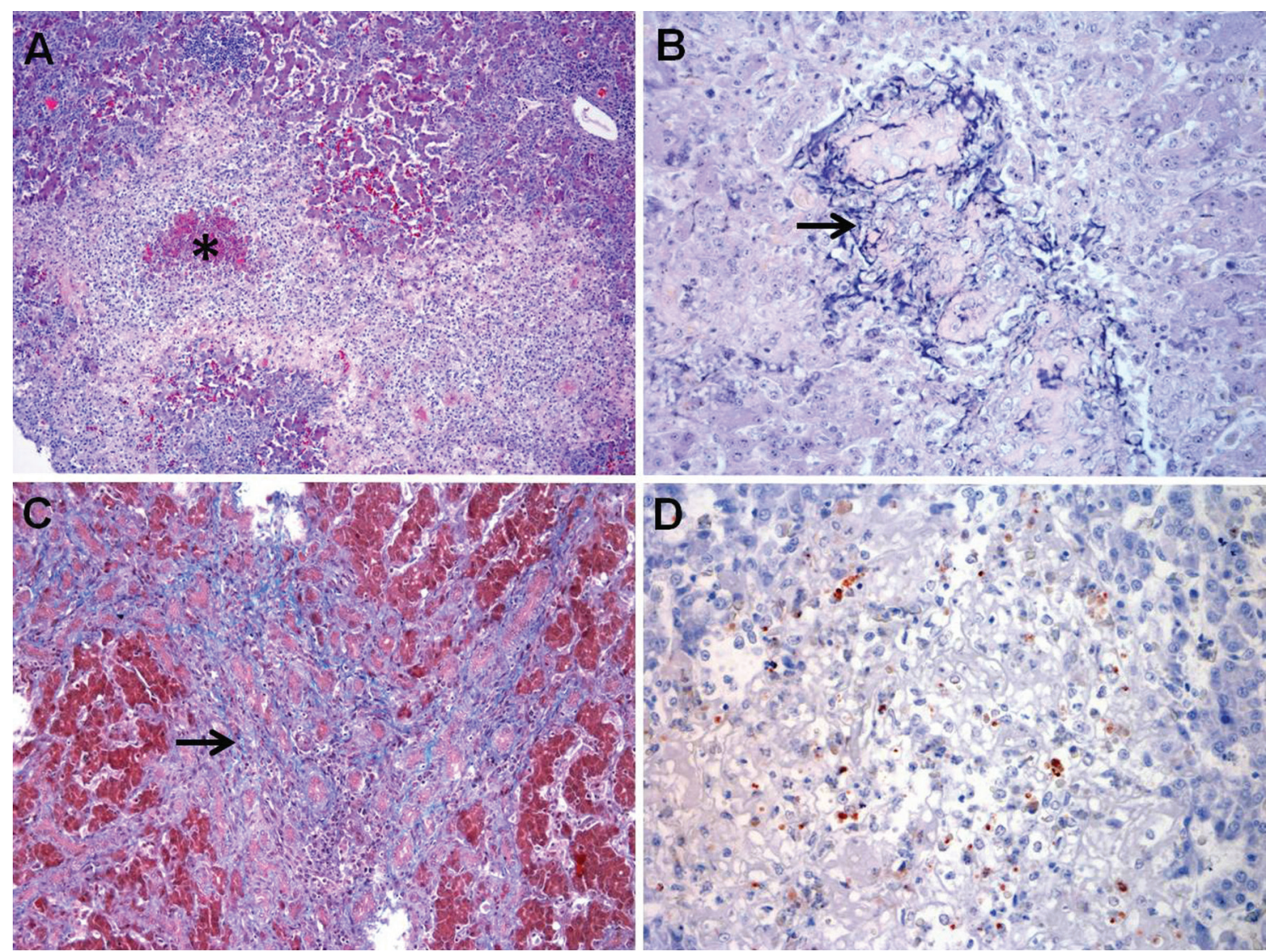

Fig.2. Cortes histológicos de fígados de frangos de corte condenados totalmente por colibacilose. (A) Hepatite necrosante aleatória (asterisco). HE, obj.10x. (B) Evidenciação de fibrina de coloração azul em meio a hepatite necrótica (seta). Hematoxilina ácida fosfotúngstica de Mallory, obj.40x. (C) Hepatite crônica-ativa com proliferação de ductos biliares e fibrose portal ou em ponte, difusa moderada (seta). Tricrômico de Masson, obj.20x. (D) Macrófagos nas áreas de hepatite com marcação anti-lisozima. Estreptavidina-biotina-peroxidase, obj.40x. 
Diagnosticou-se também hepatite aguda, caracterizada por infiltrado de heterófilos, macrófagos, linfócitos e plasmócitos multifocal moderado a acentuado. Nos casos de hepatite crônica-ativa evidenciou-se extensas áreas de necrose fibrinoide multifocal a coalescente acentuada, circundada por infiltrado de heterófilos, macrófagos, linfócitos e plasmócitos. Havia ainda proliferação de ductos biliares e fibrose portal ou em ponte, difusa moderada, que foi evidenciada pela coloração de TM (Fig.2C). Os macrófagos evidenciados nas áreas de inflamação apresentaram moderada marcação anti-lisozima (Fig.2D).

Os pulmões foram o segundo órgão com maior número de casos com lesões histológicas, apesar de não ter alterações na avaliação macroscópica. Nesse órgão diagnosticou-se bronquite fibrino-heterofílica, caracterizada por deposição de fibrina, restos celulares, infiltrado de heterófilos e macrófagos no lúmen de brônquios secundários, focal discreto. Nos casos de broncopneumonia fibrino-heterofílica, além das lesões descritas, havia inflamação no lúmen dos parabrônquios (Fig.3A). Observou-se também broncopneumonia fibrino-heterofílica necrótica caracterizada por necrose caseosa no lúmen de parabrônquios e brônquios secundários, circundada por infiltrado de macrófagos, heterófilos, linfócitos e plasmócitos focal moderado.

Utilizando a coloração de PTAH pode-se comprovar a presença dos filetes delgados de fibrina em meio ao pro- cesso inflamatório dos pulmões (Fig.3B). A IHQ utilizando marcadores celulares para caracterização do infiltrado inflamatório demonstrou que não havia proliferação de células epiteliais, pois o anticorpo anti-citoqueratina apresentava marcação apenas no epitélio de revestimento dos parabrônquios (Fig.3C), brônquios primários e secundários. Em meio ao processo inflamatório havia intensa marcação em macrófagos para lisozima (Fig.3D).

Na traqueíte linfoplasmocitária observava-se hiperplasia do epitélio discreta associada a infiltrado predominante de linfócitos e plasmócitos difuso discreto a moderado na mucosa. A pericardite, aerossaculite, salpingite, celulite e esplenite agudas caracterizavam-se por exsudação de fibrina, infiltrado de heterófilos, macrófagos, linfócitos e plasmócitos focalmente extenso discreto a moderado e, a pericardite e aerossaculite crônicas por proliferação de fibroblastos, além de infiltrado de macrófagos focal moderado.

Além das lesões de colibacilose, em 43/90 frangos havia em intestino delgado e ceco grande quantidade de Eimeria sp. em diferentes fases do desenvolvimento no citoplasma das células da mucosa, em intensidade que variava de discreta a acentuada. Os demais órgãos avaliados (rins, bursa de Fabricius, timo, medula óssea, nervo ciático, esôfago, proventrículo e moela) não apresentaram lesões anatomopatológicas.
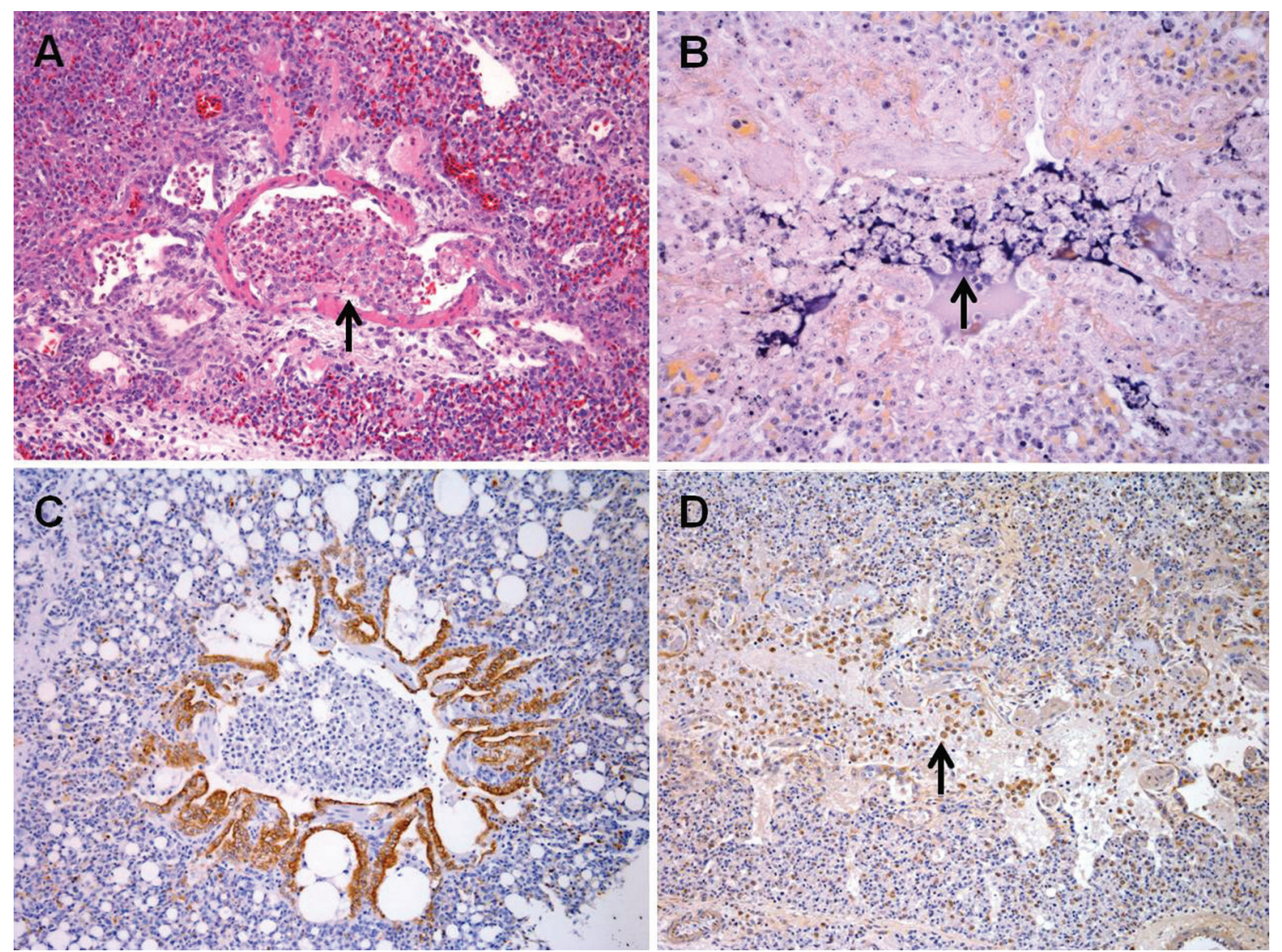

Fig.3. Cortes histológicos de pulmões de frangos de corte condenados totalmente por colibacilose. (A)) Broncopneumonia fibrino-heterofílica (seta). HE, obj.20x. (B) Evidenciação de fibrina de coloração azul em meio ao processo inflamatório (seta). Hematoxilina ácida fosfotúngstica de Mallory, obj.40x. (C) Imuno-histoquímica: Marcação anti-citoqueratina apenas no epitélio de revestimento dos parabrônquios. (D) Intensa marcação anti-lisozima em macrófagos (seta). Estreptavidina-biotina-peroxidase, obj.20x. 
Todos os pulmões e fígados que apresentaram lesões foram encaminhados para exame microbiológico. Nos 38 frangos de corte com hepatite, em 10 houve isolamento bacteriano, sendo identificado Escherichia coli $(7 / 10)$, Enterococcus sp. (1/10), Streptococcus sp. (1/10) e E. coli associado a Enterococcus sp. (1/10). Nos 14 frangos de corte que apresentavam bronquite ou broncopneumonia, em nove houve crescimento bacteriano, sendo isolado $E$. coli $(5 / 10)$ e Staphylococcus coagulase positiva $(4 / 10)$. Em nenhum desses casos isolou-se Salmonella sp.

Realizou-se PCR em tempo real para MG e MS de suabe de traqueia dos 90 frangos (casos e controles) e, todos foram negativos. A IHQ anti-MG e anti-MS dos 33 frangos em que se observou lesão no sistema respiratório, também foram negativas.

\section{DISCUSSÃo}

O serviço de inspeção de carcaças é considerado um exame de triagem (screening test). Como todo teste de triagem, erros podem ser cometidos durante a classificação das lesões observadas nos animais abatidos. Nesse estudo a condenação das carcaças total por colibacilose realizada pelo SIF e a avaliação macroscópica apresenta grau máximo de concordância. No entanto, havia discordâncias quanto a classificação das lesões. A maioria das aves foram condenadas totalmente por colibacilose por apresentarem apenas lesões hepáticas. Em sete desses frangos com lesões na avaliação macroscópica, não apresentaram lesão no exame histopatológico. Portanto, essas alterações de cor podem ser em função do abate (sangria e pendura) ou eram lesões de pouco significado, como os pontos brancos na superfície capsular hepática que podem ser devido a uma fibrose capsular discreta.

Os casos sistêmicos de infecção por Escherichia coli geralmente são causados por infecções primárias no trato respiratório que se disseminam para diversos órgãos. Nesses casos observa-se traqueíte, pneumonia, aerossaculite, pericardite e polisserosite (Janben et al. 2001, Barnes et al. 2008). Nesse estudo, nos casos condenados por colibacilose, em apenas cinco evidenciou-se essa forma disseminada, com comprometimento de sacos aéreos e demais órgãos. Em 11 casos condenados observou-se hepatite e espuma em sacos aéreos. No entanto, na maioria dos casos que havia espuma em sacos aéreos não havia lesão no exame histopatológico. Essa espuma é um indicativo de deposição de fibrina nos sacos aéreos (Fletcher et al. 2008). No entanto, nesse estudo em animais de abatedouros, que já foram eviscerados, pode ser apenas um artefato de abate.

Em frangos de corte, a maioria dos casos de colibacilose de origem respiratória, não envolvem apenas a bactéria $E$. coli. Outras enfermidades como micoplasmose, bronquite infecciosa e aspergilose, também podem estar envolvidas (Gross 1961, Fabricant \& Levine 1962, Gross 1990, Minharro et al. 2001, Ferreira \& Knöbe 2008). Nesse estudo não se observou lesões sugestivas de aspergilose e todos os lotes eram vacinados para bronquite infecciosa. A traqueíte linfoplasmocitária observada em algumas aves pode ser uma resposta da vacina contra o vírus da bronquite (Cavanagh \& Gelb 2008).
Em galinhas, a infecção por MG pode causar a Doença Respiratória Crônica (DRC), geralmente com o envolvimento de E. coli (Gross 1961, Fabricant \& Levine 1962, Gross 1990, Minharro et al. 2001). No entanto, nesse estudo em nenhum caso de colibacilose com lesão no sistema respiratório, identificou-se MG e MS pela PCR em tempo real ou pela IHQ anti-MG e anti-MS. Isso demonstra o esforço de muitas empresas brasileiras, através de corretos programas de biosseguridade, para eliminar esses agentes dos plantéis. Buim et al. (2009) realizaram PCR para MG e MS de suabe traqueal e embriões bicados de 33 estabelecimentos de aves de postura, matrizes, frangos de corte e um incubatório, localizados nos estados de São Paulo, Paraná e Pernambuco, os quais apresentavam problemas respiratórios ou queda na produção de ovos. A prevalência de MS e MG foi de 33,33\% e 9,09\% respectivamente.

Em um estudo em abatedouro sob SIF no estado do Rio Grande do Sul identificou-se, pela PCR, MG de suabe de traqueia em $20 \%$ dos lotes avaliados (8/40). Nesse trabalho havia relação entre a positividade de $\mathrm{MG}$ com aumento na condenação por aerossaculite e com o baixo peso dos lotes (Machado et al. 2012). Já em abatedouros sob SIF no estado de Goiás identificou-se pela PCR do saco aéreo de frangos de corte condenados por aerossaculite MG em 32,2\% (10/31) dos lotes, MS em 25,8\% (8/31) e isolou-se E. coli em 80,6\% (25/31). Houve associação de E. coli com MS, MG e com ambos em $16,13 \%(5 / 31), 12,9 \%$ (4/31) e $9,68 \%$ (3/31) respectivamente (Minharro et al. 2001).

As condições ambientais e de manejo também podem contribuir grandemente para a ocorrência de colibacilose, já que a bactéria é considerada oportunista. Altas concentrações de amônia no galpão, deficiências na ventilação, extremos de temperatura, umidade da cama, criações com alta densidade e deficiência no processo de limpeza e desinfecção são considerados os principais fatores ambientais predisponentes (Ferreira \& Knöbe, 2008).

E. coli patogênica para aves (APEC), também pode ter origem intestinal, e nessa forma comumente se visualiza hepatite e esplenite fibrinonecróticas, que pode se disseminar para diversos órgãos (Newberry et al. 1993, Barnes et al. 2008). A maioria das aves condenadas por colibacilose apresentaram apenas lesões hepáticas, o que pode sugerir uma origem bacteriana intestinal. Um grande número dos frangos apresentou lesões intestinais causada por Eimeria sp. Portanto, esse protozoário pode ter causado injúrias, favorecendo a penetração da APEC na mucosa intestinal e colonização de outros órgãos, como o fígado (Barnes et al. 2008, Kabir 2010).

A IHQ com marcadores celulares para citoqueratina e lisozima foi utilizada para caracterizar o processo inflamatório observado em pulmão e fígado. Em casos de lesões pulmonares nas aves, o epitélio que reveste os parabrônquios pode tornar-se hipertrófico, hiperplásico e em alguns casos até fagocítico (Fletcher et al. 2008). Portanto, com a IHQ anti-citoqueratina foi possível evidenciar que o epitélio não sofreu essas alterações nesses casos de broncopneumonia e que tanto nos casos de hepatite como de broncopneumonia há infiltração de macrófagos que apresentam marcação anti-lisozima. 
Nos 38 frangos de corte com hepatite, em apenas 10 houve isolamento bacteriano. Esse baixo índice pode ter ocorrido devido ao fato do agente infeccioso já ter sido combatido pelo organismo, apesar da lesão ainda estar presente. Outras possíveis causas é que nesse estudo não se realizou a pesquisa de bactérias anaeróbicas e todas as amostras foram congeladas, podendo afetar a viabilidade. Infecção subclínica por Clostridium perfringens em frangos pode causar hepatite e colângio-hepatite com condenação desse órgão (Lovland \& Kaldhusdal 1999, Barcelos et al. 2006). Essas lesões hepáticas podem estar relacionadas a enterite necrótica causada por C. perfringens (Lovland \& Kaldhusdal 1999). Clostridium perfringens é um patógeno oportunista, presente no intestino das aves, e a lesão causada pela infecção por Eimeria sp. tem sido considerada como um importante fator predisponente da enterite necrótica (Van Immerseel et al. 2004).

Nesse estudo além de E. coli, outras bactérias como Staphylococcus coagulase positiva, Enterococcus sp. e Streptococcus sp. foram isoladas dos casos de hepatite e broncopneumonia. Essas bactérias, comumente fazem parte da microbiota do sistema digestório e respiratório, podem causar infecções sistêmicas aguda ou crônica, geralmente secundária a lesões causadas por outros agentes ou fatores imunossupressores (Peckham 1966, Sandhu 1988, Linares \& Wigle 2001).

\section{CONCLUSÕES}

Através dos resultados obtidos nesse estudo pode-se concluir que: 1) a condenação das carcaças total por colibacilose, realizada pelo SIF, apresentou grau máximo de concordância com a avaliação macroscópica post mortem;

2) o fígado foi o principal órgão acometido por lesões, sendo assim, nesses casos, o critério de condenação deveria ser reavaliado, sugerindo condenação por hepatite e não por colibacilose, uma vez que diversas espécies de bactérias podem causar hepatite em frangos;

3) colibacilose com envolvimento respiratório apresentou baixa prevalência e nenhum desses casos foi relacionado a infecção por MG e MS;

4) além de E. coli, outras bactérias também foram isoladas dos frangos condenados por colibacilose;

5) um grande percentual dos frangos apresentaram lesões causadas por Eimeria sp., portanto mais estudos devem ser conduzidos para determinar a real importância desse agente como fator desencadeante de processos infecciosos bacterianos em frangos de corte.

\section{REFERÊNCIAS}

Alencar A.P., Nascimento E.R., Danelli M.G.M., Lignon G.B., Santos M.A.J. \& Nascimento M.G.F. 1998. Relação entre infecção por Mycoplasma gallisepticum e M. synoviae e lesões de sacos aéreos em frangos de corte. Revta Bras. Med. Vet. 20:257-262.

Ansong-Danquah J. 1987. A survey of carcass condemnation at a poultry abattoir and its application to disease management. Can. Vet. J. 28:53-56.

Barcelos A.S., Flôres M.L., Kommers G.D., Nascimento V.P., Segabinazi S.D., Antoniazzi T. \& Bassan J.D.L. 2006. Macroscopia, histopatologia e bacteriologia de fígados de frangos (Gallus gallus) condenados no abate. Ciência Rural 36:561-567.
Barnes H.J., Nolan L.K. \& Vaillancourt J.P. 2008. Colibacillosis, p.691-737. In: Saif Y.M. (Ed.), Diseases of Poultry. 12th ed. Blackwell, Iowa.

Brasil 1998. Portaria no 210, de 10 de novembro de 1998. Regulamento Técnico da Inspeção Tecnológica e Higiênico-Sanitária de Carne de Aves. In: Ministério da Agricultura, Pecuária e Abastecimento, Brasil (Ed.), Diário Oficial da União. Brasília, p.17-22, de 5 de março de 1999, Seção I.

Buim M.R., Mettifogo E. \& Timenetsky J. 2009. Epidemiological survey on Mycoplasma gallisepticum and M. synoviae by multiplex PCR in commercial poultry. Pesq. Vet. Bras. 29:552-556.

Casagrande R.A., Castro L.A., Rolim V.M., Wouters F., Boabaid F.M., Souza S.O., Guerra P., Silva S.C. \& Driemeier D. 2014. Diagnóstico imuno-histoquímico e caracterização anatomopatológica de Mycoplasma gallisepticum em galinhas de subsistência. Pesq. Vet. Bras. 34:153-161.

Cavanagh D. \& Gelb J. 2008. Infectious bronchitis, p.117-135. In: Saif Y.M. (Ed.), Diseases of Poultry. 12th ed. Blackwell, Iowa.

Fabricant J. \& Levine P.P. 1962. Experimental production of complicated chronic respiratory disease infection ("air sac" disease). Avian Dis. 6:1323.

Ferreira A.J.P. \& Knöbe T. 2008. Enfermidades bacterianas, p.435-563. In: Berchieri Jr A. \& Macari M. (Eds), Doenças das Aves. FACTA, Campinas.

Fletcher 0.J., Abdul-Aziz T. \& Barnes H.J. 2008. Respiratory system, p.128163. In: Fletcher O.J. (Ed.), Avian Histopathology. Omni Press, Madison.

Giotto D.B., Zimermann F.C., Cesco M.A.O., Fortes F.B., Pinheiro D., Hiller C.C., Herpich J., Medina M., Rodrigues E. \& Salle C.T.P. 2008. Impacto econômico de condenações post mortem de frango de corte em um matadouro frigorifico na região sul do Brasil. Disponível em <http://www. sovergs.com.br/conbravet2008/anais/cd/resumos/R0701-2.pdf> Acesso em 10 jan. 2012.

Gross W.B. 1961. The development of "air sac disease". Avian Dis. 5:431439.

Gross W.B. 1990. Factors affecting the development of respiratory disease complex in chickens. Avian Dis. 34:607-610.

Janben T., Schwarz C., Preikschat P., Voss M. Philipp H.C. \& Wieler L.H. 2001. Virulence-associated genes in avian pathogenic Escherichia coli (APEC) isolated from internal organs of poultry having died from colibacillosis. Int. J. Med. Microbiol. 291:371-378.

Kabir S.M.L. 2010. Avian colibacillosis and salmonellosis: a closer look at epidemiology, pathogenesis, diagnosis, control and public health concerns. Int. J. Environ. Res. Public Health 7:89-114.

Kleven S.H. \& Ferguson-Noel N. 2008. Mycoplasma synoviae infection, p.845856. In: Saif Y.M. (Ed.), Diseases of Poultry. 12th ed. Blackwell, Iowa.

Ley D.H. 2008. Mycoplasma gallisepticum infection, p.807-834. In: Saif Y.M. (Ed.), Diseases of Poultry. 12th ed. Blackwell, Iowa.

Linares J.A. \& Wigle W.L. 2001. Staphylococcus aureus pneumonia in turkeys poults with gross lesions resembling aspergillosis. Avian Dis. 45:1068-1072.

Lovland A. \& Kaldhusdal M. 1999. Liver lesions seen at slaughter as an indicator of necrotic enteritis in broiler flocks. FEMS Immunol. Med. Microbiol. 24:345-351.

Machado L.S., Nascimento E.R., Pereira V.L.A., Almeida D.O., Silva R.C.F. \& Santos L.M.M. 2012. Mycoplasma gallisepticum como fator de risco no peso de lotes de frangos de corte com condenação por aerossaculite na Inspeção Sanitária Federal. Pesq. Vet. Bras. 32:645-648.

Minharro S., Linhares G.F.C., Andrade M.A., Rocha P.T. \& Santana A. P. 2001. Envolvimento de Escherichia coli, de Mycoplasma gallisepticum e de Mycoplasma synoviae em lesões de sacos aéreos em frangos abatidos no Estado de Goiás. Ciênc. Anim. Bras. 2:111-117.

Newberry L.A., Skeeles J.K., Kreider D.L., Beasley J.N., Story J.D., McNew R.W. \& Berridge B.R. 1993. Use of virulent hemorrhagic enteritis virus for the induction of colibacillosis in turkeys. Avian Dis. 37:1-5.

R Development Core Team 2011. R: A language and environment for statistical computing. R Foundation for Statistical Computing, Vienna. Available at: <http://www.R-project.org>

Peckham M.C. 1966. An outbreak os streptococcosis (apoplectiform septicemia) in white rock chicken. Avian Dis. 10:413-421. 
Sandhu T. S. 1988. Fecal streptococcal infection of commercial white pekin ducklings. Avian Dis. 32:570-573.

Sentíes-Cué G., Shivaprasad H.L. \& Chin R.P. 2005. Systemic Mycoplasma synoviae infection in broiler chickens. Avian Pathol. 34:137-142.

Sesterhenn R., Ferreira T.Z., Kindlein L. \& Moraes H.L.S. 2011. Impacto econômico de condenações post mortem de aves sob inspeção estadual no Estado do Rio Grande do Sul. Disponível em <http://www.sovergs.com. br/site/38conbravet/resumos/797.pdf> Acesso em 10 fev. 2012.

Van Immerseel F., De Buck J., Pasmans F., Huyghebaert G., Haesebrouck
F. \& Ducatelle R. 2004. Clostridium perfringens in poultry: an emerging threat for animal and public health. Avian Pathol. 33:537-549.

Yilmaz F., Timurkaan N., Kiliç A., Kalender H. \& Kilinç Ü. 2011a. Detection of Mycoplasma synoviae and Mycoplasma gallisepticum in chicken by immunohistochemical, PCR and culture methods. Revue Méd. Vét. 162:7986.

Yilmaz F. \& Timurkaan N. 2011b. Detection of Mycoplasma gallisepticum and Mycoplasma synoviae antigens by immunohistochemical method in pneumonic broiler chicken lungs. J. Anim. Vet. Adv. 10:2557-2560. 